\title{
HUBUNGAN FAKTOR-FAKTOR SOSIAL EKONOMI PETANI DAN TINGKAT ADOPSI INOVASI BUDIDAYA PADI DI DESA KEMBANG MERTHA, KECAMATAN DUMOGA TIMUR, KABUPATEN BOLAANG MONGONDOW
}

\author{
Defry Kristian Rai Wongkar \\ Welson M. Wangke \\ Agnes E. Loho \\ Melissa L. G. Tarore
}

\begin{abstract}
The objective of the research is to determine farmer's socio-economic characteristics, the paddy's cultivation innovation adoption degree and the relationship between farmer's socio-economic factors with the degree of paddy's (Oryza sativa L.) cultivation innovation adoption in Kembang Merta Village. This research is using descriptive statistic analytic method with survey technique. The study location is taken on purpose base. Kembang Mertha Village was chosen because it is one of rice production center in Bolaang Mongondow Regency. The sample was taken from 48 people by using stratified random sampling technique based on the farmer's rice field area. The correlation test of Rank Spearman using SPSS 17 Program is used to examine the relationship between farmer's socio-economic factors with the degree of paddy (Oryza sativa L.) cultivation innovation adoption. Research result showed that mostly respondents have $1.1-2 \mathrm{Ha}$ paddy field area with income about Rp. 11.000.000- Rp. 15.000.000 every planting season. Mostly respondents are 40 to 50 years old that classified as productive ages and mostly were senior school graduates. The non-formal education only once to four times a year and the cosmopolitan respondents only three times a year. The degree of Paddy (Oryza sativa L.) cultivation innovation adoption observed from paddy's cultivation stages. The soil plowing process in median 5, planting paddy in median 5, fertilization in median 4, irrigation in median 5, the pests, diseases and weeds control in median 5 and harvest and post-harvest in median 5. Correlation test indicated that land area, income, formal education and cosmopolitan level are significant to rice cultivation innovation adoption, whereas non-formal education and ages indicated insignificant relation to rice cultivation innovation adoption. *jnd
\end{abstract}

Keywords: Paddy farmers, socio-economic factors, cultivation innovation, adoption degree,, Kembang Merta Village, Bolaang Mongondow

\section{ABSTRAK}

Tujuan penelitian ini untuk mengetahui karakteristik sosial ekonomi petani, tingkat adopsi inovasi budidaya padi (Oryza sativa L.) dan hubungan faktor-faktor sosial ekonomi petani dengan tingkat adopsi inovasi budidaya padi. di Desa Kembang Mertha. Penelitian ini menggunakan metode analisis statistik deskriptif dengan teknik survey. Penentuan lokasi penelitian dilakukan secara sengaja berdasarkan maksud penelitian. Desa Kembang Mertha dipilih karena merupakan salah satu daerah sentra produksi tanaman padi (Oryza sativa L.) di Kabupaten Bolaang Mongondow. Sampel diambil sebanyak 48 orang dengan menggunakan teknik sampel acak berstrata berdasarkan luas lahan usahatani. Untuk mengkaji hubungan faktor-faktor sosial ekonomi petani dengan tingkat adopsi inovasi teknologi budidaya tanaman Padi (Oryza sativa L.) adalah dengan menggunakan uji korelasi Rank Spearman ( $\gamma \mathrm{s})$ menggunakan Program SPSS 17. Hasil penelitian menunjukkan bahwa: luas lahan usahatani sebagian besar responden yaitu 1,1 - 2 Ha dengan pendapatan berkisar antara Rp. 11.000.000 - Rp. 15.000.000 per musim tanam. Sebagian besar responden berumur 40-50 tahun, yang tergolong kategori usia produktif. Jenjang pendidikan terakhir sebagian besar responden ialah tamat SMU/SMK. Pendidikan non-formal petani hanya sebanyak 1 sampai 4 kali dalam satu tahun, serta tingkat kosmopolitan responden sebanyak 3 kali dalam satu tahun. Sedangkan tingkat adopsi inovasi budidaya padi dilihat dari tahapan-tahapan budidaya padi. Pengolahan Tanah pada median 5, Penanaman Padi pada median 5, Pemupukan pada median 4, Pengairan pada median 5, Pengendalian hama, Penyakit dan Gulma pada median 5, Panen dan Pascapanen pada median 5. Uji korelasi menunjukkan bahwa luas lahan, pendapatan, dan tingkat kekosmopolitan berhubungan sangat nyata dengan tingkat adopsi inovasi budidaya padi, sedangkan pendidikan formal, pendidikan non-formal dan umur menunjukkan tidak berhubungan yang nyata dengan tingkat adopsi inovasi budidaya padi.

Kata kunci: Petani Padi, faktor sosial ekonomi, tingkat adopsi inovasi budidaya, Desa Kembang Mertha, Kabupaten Bolaang Mongondow. 


\section{PENDAHULUAN}

\section{Latar Belakang}

Inti dari kegiatan penyuluhan pertanian merupakan komunikasi gagasan maupun teknologi yang inovatif dan dapat memberikan nilai ekonomis yang lebih bagi para petani dan keluarganya. Dengan mengadopsi suatu inovasi, maka tujuan jangka panjang seperti, better farming, better business, dan better living dapat terwujud melalui metode metode inovasi tersebut, yakni melalui peningkatan produksi. Dengan demikian, adopsi inovasi merupakan intisari dari kegiatan penyuluhan pertanian (Levis, 1996).

Salah satu tanaman pangan yang penting ialah padi (Oryza sativa L.) yang menghasilkan beras. Beras merupakan hasil proses penggilingan maupun penumbukan gabah padi kering, yang telah dipisahkan dengan sekamnya. Jenis tanaman padi yang banyak diusahakan petani adalah jenis padi sawah. Kebutuhan akan beras di Indonesia meningkat setiap tahunnya, seiring dengan semakin bertambahnya jumlah penduduk yang mencapai $1,44 \%$ per tahun. Dengan produksi sebesar 66 juta metrik ton gabah kering giling (GKG) pada tahun 2010, Indonesia hanya mengisi 9\% dari total produksi padi dunia, Sedangkan untuk memenuhi kebutuhan pangan nasional, pemerintah masih mengimpor beras dari Vietnam dan Thailand. Kondisi tersebut mendorong pemerintah Indonesia untuk menempuh kebijakan berupa Program Peningkatan Produksi Beras Nasional (P2BN) guna memenuhi kebutuhan pangan nasional. Swasembada pangan ini dimaksudkan agar Indonesia tidak lagi bergantung pada ekspor beras dari negara lain (Panelewen, 2010).

Di Sulawesi Utara sendiri, berdasarkan validasi data Dinas Pertanian dan Dinas PU tahun 2010, potensi lahan sawah di Sulawesi Utara seluas 55.855 ha dengan produksi 584.030 ton GKG, dianggap potensial dan perlu ditingkatkan lagi guna mendukung terciptanya Swasembada Pangan Nasional. Strategi yang ditempuh pemerintah untuk mewujudkan tujuan tersebut antara lain: perluasan areal dan pengolahan lahan, peningkatan produktivitas melalui penerapan teknologi, penurunan konsumsi beras dan penyempurnaan managemen (Panelewen, 2010).
Adopsi inovasi dapat diartikan sebagai penerapan atau penggunaan suatu ide, alat-alat, atau teknologi "baru" yang disampaikan berupa pesan komunikasi (lewat penyuluhan). Manifestasi dari bentuk adopsi inovasi ini dapat dilihat atau diamati berupa tingkah laku, metode, maupun peralatan dan teknologi yang dipergunakan dalam kegiatan usahataninya (Levis, 1996).

Berkaitan dengan pelaksanaan komunikasi berbagai paket inovasi atau paket penyuluhan ke-tengah-tengah masyarakat desa, masih saja ada kesenjangankesenjangan (missunderstanding), banyak faktor yang dapat mempengaruhi tingkat adopsi inovasi teknologi petani mengenai pemahaman pembangunan pertanian. Faktorfaktor tersebut antara lain faktor sosial ekonomi petani yaitu luas usahatani, pendapatan, pendidikan formal, pendidikan non-formal, umur, dan tingkat kosmopolitan, diduga faktor-faktor inilah yang mempengaruhi keberhasilan adopsi suatu inovasi teknologi yang dibagikan. Pemahaman mengenai adopsi inovasi budidaya tanaman padi setiap petani berbeda-beda dalam mengadopsi suatu inovasi, misalnya cara menanggapi suatu inovasi, tingkat pemahaman terhadap suatu inovasi dan sebagainya, hal itu tergantung faktor-faktor sosial ekonomi petani tersebut.

Penelitian tentang hubungan faktorfaktor sosial ekonomi terhadap tingkat adopsi inovasi budidaya padi dilaksanakan di Desa Kembang Mertha Kecamatan Dumoga Timur, karena daerah tersebut berperan sebagai salah satu daerah produsen beras di Kabupaten Bolaang Mongondow, Provinsi Sulawesi Utara.

\section{Rumusan Masalah}

Tingkat adopsi petani terhadap inovasi budidaya padi dan faktor-faktor yang mempengaruhinya perlu dikaji sebagai dasar untuk menerapkan strategi yang diperlukan dalam rangka mendukung tujuan jangka panjang seperti, better farming, better business, dan better living dapat terwujud melalui metode metode inovasi tersebut. Berkaitan dengan hal tersebut maka timbul pertanyaan sebagai berikut: 
1. Bagaimana karakteristik sosial ekonomi petani di Desa Kembang Mertha?

2. Bagaimana tingkat adopsi inovasi budidaya padi (Oryza sativa L.) di Desa Kembang Mertha?

3. Bagaimana hubungan faktor-faktor sosial ekonomi petani dengan tingkat adopsi inovasi budidaya padi (Oryza sativa L.) di Desa Kembang Mertha?

\section{Tujuan Penelitian}

Adapun tujuan dari penelitian ini adalah sebagai berikut:

1. Untuk mengetahui karakteristik sosial ekonomi petani di Desa Kembang Mertha

2. Untuk mengetahui tingkat adopsi inovasi budidaya padi (Oryza sativa L.) di Desa Kembang Mertha

3. Untuk mengetahui hubungan faktor-faktor sosial ekonomi petani dengan tingkat adopsi inovasi teknologi budidaya padi (Oryza sativa L.) di Desa Kembang Mertha

\section{Manfaat Penelitian}

1. Bagi pemerintah dan instansi terkait, diharapkan dapat menjadi bahan pertimbangan dalam menentukan kebijakan pembangunan pertanian.

2. Bagi petani atau penerap inovasi di Desa Kembang Mertha, diharapkan dapat menjadi motivasi dalam mengadopsi dan mengembangkan inovasi teknologi budidaya padi (Oryza sativa L.).

\section{METODOLOGI PENELITIAN}

\section{Waktu dan Lokasi Penelitian}

Pengambilan lokasi dilakukan secara sengaja karena berdasarkan ciri-ciri atau sifatsifat yang diketahui sebelumnya sesuai dengan kepentingan penelitian. Desa Kembang Mertha dipilih karena merupakan salah satu daerah sentra produksi padi (Oryza sativa L.) di Kabupaten Bolaang Mongondow.

Penelitian dilaksanakan mulai bulan Januari 2015 - Mei 2015 di Desa Kembang Mertha (bersatu) yaitu Desa Kembang Sari, Desa Kembang Mertha, Desa Amertha
Buana, dan Desa Amertha Sari. Kecamatan Dumoga Timur Kabupaten Bolaang Mongondow.

\section{Pengumpulan Data}

Pengambilan data dilakukan dengan teknik survei. Dalam teknik survei, informasi yang dikumpulkan dari responden dengan menggunakan kuisioner. Data yang dikumpulkan berupa data primer dan data sekunder.

Data primer diperoleh wawancara berdasarkan daftar pertanyaan yang sudah disusun sebelumnya kepada petani padi yang ada di Desa Kembang Mertha Bersatu, yaitu Desa Kembang Sari, Desa Kembang Mertha, Desa Amertha Buana, dan Desa Amertha Sari. Data sekunder diperoleh dari Dinas Pertanian dan Peternakan Sulawesi Utara, Badan Pusat Statistik Kabupaten Bolaang Mongondow, Pemerintah Desa Kembang Mertha dan bukubuku yang terkait dengan penelitian ini.

\section{Metode Pengambilan Sampel}

Pengambilan data dilakukan dengan membagikan kuisioner kepada petani, dan penentuan sampel dilakukan dengan metode Stratified Random Sampling, yaitu pengambilan sampling dengan memperhatikan strata/tingkatan (Soehartono, 2004). Responden dipilih berdasarkan luas lahan yang diusahakan, tujuannya untuk mewakili setiap strata luas lahan.

\section{Hipotesis Penelitian}

a. Diduga ada hubungan nyata antara luas lahan usaha tani dengan tingkat adopsi inovasi budidaya padi (Oryza sativa L.) pada petani.

b. Diduga ada hubungan nyata antara pendapatan dengan tingkat adopsi inovasi budidaya padi (Oryza sativa L.) pada petani.

c. Diduga ada hubungan nyata antara pendidikan formal dengan tingkat adopsi inovasi budidaya padi (Oryza sativa L.) pada petani.

d. Diduga ada hubungan nyata antara pendidikan non formal dengan tingkat adopsi inovasi budidaya padi (Oryza sativa L.) pada petani.

e. Diduga ada hubungan nyata antara umur petani dengan tingkat adopsi inovasi 
budidaya padi (Oryza sativa L.) pada petani.

f. Diduga ada hubungan nyata antara tingkat kekosmopolitan petani dengan tingkat adopsi inovasi budidaya padi (Oryza sativa L.) pada petani.

Kriteria uji :

g. Jika Sig. $\leq \alpha(0,1)$ berarti ada hubungan nyata antara kedua variabel.

h. Jika Sig. $>\alpha(0,1)$ berarti tidak ada hubungan yang nyata antara kedua variabel.

\section{Pengukuran Variabel}

Pengukuran Variabel Karakteristik Sosial Ekonomi Petani, pengukuran variabel sosial ekonomi disajikan dalam Tabel 1.

Tahap olah tanah ialah sebagai tahap awal suatu proses budidaya. Pengukuran Tahap olah tanah ialah sebagai tahap awal suatu proses budidaya. Pengukuran variabel tahap pengolahan tanah disajikan dalam Tabel 2.

Tabel 1. Pengukuran Variabel Karakteristik sosial Ekonomi Petani

\begin{tabular}{|c|c|c|c|}
\hline Variabel & Indikator & Kriteria & Skor \\
\hline $\begin{array}{l}\text { Luas Lahan } \\
\text { Usahatani }\end{array}$ & $\begin{array}{l}\text { Luas Lahan yang } \\
\text { diusahakan }\end{array}$ & $\begin{array}{l}>3 \mathrm{Ha} \\
2,1-3 \mathrm{Ha} \\
1,1-2 \mathrm{Ha} \\
0,5-1 \mathrm{Ha} \\
<0,5 \mathrm{Ha}\end{array}$ & $\begin{array}{l}5 \\
4 \\
3 \\
2 \\
1\end{array}$ \\
\hline Pendapatan & $\begin{array}{l}\text { Pendapatan } \\
\text { bersih Petani } \\
\text { dalam1 kali } \\
\text { musim tanam }\end{array}$ & $\begin{array}{l}>\text { Rp } 15.000 .000 \\
\text { Rp } 10.000 .050-\operatorname{Rp} 15.000 .000 \\
\text { Rp. } 7.500 .000-\operatorname{Rp} 10.000 .000 \\
\text { Rp. } 5.000 .000-\operatorname{Rp} 7.000 .000 \\
\text { < Rp. 5.000.000 }\end{array}$ & $\begin{array}{l}5 \\
4 \\
3 \\
2 \\
1\end{array}$ \\
\hline $\begin{array}{l}\text { Pendidikan } \\
\text { Formal }\end{array}$ & $\begin{array}{l}\text { Pendidikan } \\
\text { formal yang telah } \\
\text { ditempuh petani }\end{array}$ & $\begin{array}{l}>\text { SMU/SMK } \\
\text { SMU/SMK } \\
\text { SMP } \\
\text { SD } \\
\text { Tidak Tamat SD }\end{array}$ & $\begin{array}{l}5 \\
4 \\
3 \\
2 \\
1\end{array}$ \\
\hline $\begin{array}{l}\text { Pendidikan } \\
\text { Non-Formal }\end{array}$ & $\begin{array}{l}\text { Frekuensi Petani } \\
\text { mengikuti } \\
\text { kegiatan } \\
\text { penyuluhan } \\
\text { dalam } 1 \text { Tahun }\end{array}$ & $\begin{array}{l}>12 \\
10-12 \text { kali } \\
5-9 \text { kali } \\
1-4 \text { kali } \\
\text { Tidak Pernah }\end{array}$ & $\begin{array}{l}5 \\
4 \\
3 \\
2 \\
1\end{array}$ \\
\hline Umur & $\begin{array}{l}\text { Umur petani saat } \\
\text { pengambilan data }\end{array}$ & $\begin{array}{l}25-39 \text { Tahun } \\
40-50 \text { Tahun } \\
51-60 \text { Tahun } \\
61-70 \text { Tahun } \\
>\text { 70Tahun }\end{array}$ & $\begin{array}{l}5 \\
4 \\
3 \\
2 \\
1\end{array}$ \\
\hline $\begin{array}{l}\text { Tingkat } \\
\text { Kosmopolitan }\end{array}$ & $\begin{array}{l}\text { Frekuensi } \\
\text { responden pegi } \\
\text { ke Kota dalam } 1 \\
\text { bulan }\end{array}$ & $\begin{array}{l}\geq 6 \text { kali } \\
5 \text { kali } \\
4 \text { kali } \\
3 \text { kali } \\
1-2 \text { kali }\end{array}$ & $\begin{array}{l}5 \\
4 \\
3 \\
2 \\
1\end{array}$ \\
\hline
\end{tabular}


Tabel 2. Pengukuran Variabel Pengolahan Tanah

\begin{tabular}{|c|c|c|c|}
\hline Variabel & Indikator & Kriteria & Skor \\
\hline $\begin{array}{l}\text { Pengolahan } \\
\text { tanah }\end{array}$ & $\begin{array}{l}\text { a. Melakukan pembersihan } \\
\text { lahan. } \\
\text { b. Melakukan pembajakan tanah } \\
\text { yang sebelumnya telah } \\
\text { digenangi air dengan } \\
\text { menggunakan traktor/ bajak } \\
\text { (pembajakan) } \\
\text { c. Melakukan Penggaruan untuk } \\
\text { menghancurkan bongkahan- } \\
\text { bongkahan tanah menjadi } \\
\text { lebih kecil (penggaruan) } \\
\text { d. Penghancuran lapisan tanah } \\
\text { hingga menjadi lumpur } \\
\text { dilakuakn bersamaan dengan } \\
\text { pengairan (Pelumpuran) } \\
\text { e. Pembuatan petakan sawah } \\
\text { f. Persiapan lahan penanaman }\end{array}$ & $\begin{array}{l}\text { a.Melakukan } 5-6 \text { tahapan } \\
\text { pengolahan tanah } \\
\text { b. Melakukan } 3-4 \\
\text { tahapan pengolahan tanah } \\
\text { c.Melakukan } 2 \text { tahapan } \\
\text { pengolahan tanah } \\
\text { d. Melakukan } 1 \text { tahapan } \\
\text { pengolahan tanah } \\
\text { e. Tidak melakukan tahapan } \\
\text { pengolahan tanah }\end{array}$ & 3 \\
\hline
\end{tabular}

Tabel 3. Pengukuran Variabel Penanaman

\begin{tabular}{|c|c|c|c|}
\hline Variabel & Indikator & Kriteria & Skor \\
\hline Penanaman & $\begin{array}{l}\text { a. Penjemuran benih selama 1- } \\
2 \text { jam } \\
\text { b. Seleksi benih dilakukan } \\
\text { dengan merendam, benih } \\
\text { yang baik adalah yang } \\
\text { tenggelam, pengaplikasian } \\
\text { fungisida, dicampur } \\
\text { bersama air rendaman } \\
\text { c. benih terpilih kemudian } \\
\text { ditiriskan } \\
\text { d. Pemeraman selama } \pm 48 \\
\text { jam } \\
\text { e. Benih ditabur pada areal } \\
\text { penanaman dengan } \\
\text { kerapatan } \pm 50 \mathrm{gr} / 1 \mathrm{~m}^{2}\end{array}$ & $\begin{array}{ll}\text { a. } & \text { Melakukan } 5 \text { tahapan } \\
\text { penanaman } \\
\text { b. Melakukan } 4 \text { tahapan } \\
\text { penanaman } \\
\text { c. Melakukan } 3 \text { tahapan } \\
\text { penanaman } \\
\text { d. Melakukan } 2 \text { tahapan } \\
\text { penanaman } \\
\text { e. Melakukan hanya } 1 \\
\text { tahapan penanaman }\end{array}$ & 2 \\
\hline
\end{tabular}

Penanaman diawali dengan persiapan benih. Penanaman padi dilakukan dengan menggunakan Teknik TABELA. Pengukuran tahap penanaman disajikan dalam Tabel 3. Sedangkan pada Tabel 4 dapat dilihat Variabel Pemupukan.
Ketersediaan air pada areal pertanian memegang peranan penting dalam menunjang produksi tanaman padi. Keberhasilan metode pengairan yang teratur tidak hanya untuk kebutuhan tanaman padi, namun juga berpengaruh pada pengendalian hama, 
penyakit dan gulma. Oleh karena itu, pengontrolan ketinggian genangan air pada lahan sawah menjadi sangat penting dalam budidaya padi sawah. pengukuran variabel pada tahap pengairan disajikan dalam Tabel 5 .

Mengidentifikasi adanya gejala serangan-serangan hama dan penyakit pada areal pertanaman dianjurkan dilakukan secara berkala dan kontinyu, agar pengendalian dapat dilakukan secara efektif dan tepat guna. Pengendalian dilakukan apabila terdapat gejala serangan, dapat dilakukan secara fisik, biologis, kimia, maupun kultur tenis. Pengukuran variabel pada tahap pengendalian hama, penyakit serta gulama disajikan dalam Tabel 6 :

Tabel 4. Pengukuran Variabel pemupukan

\begin{tabular}{|c|c|c|c|}
\hline Variabel & Indikator & Kriteria & Skor \\
\hline \multirow[t]{6}{*}{ Pemupukan } & $\begin{array}{l}\text { a. Pemupukan ORGANIK dasar } \\
\text { berupa pupuk kandang saat } \\
\text { pengolahan tanah }\end{array}$ & $\begin{array}{l}\text { a. Pengaplikasian semua jenis } \\
\text { pemupukan }\end{array}$ & 5 \\
\hline & $\begin{array}{l}\text { b. Pemupukan ANORGANIK dasar } \\
\text { saat lahan telah selesai diolah, } \\
\text { berupa pupuk TSP,KCL, serta }\end{array}$ & $\begin{array}{l}\text { b. Pengaplikasian semua pupuk } \\
\text { tanpa pupuk kandang }\end{array}$ & 4 \\
\hline & $1 / 3$ pupuk UREA & c. Pengaplikasian semua pupuk & 3 \\
\hline & $\begin{array}{l}\text { c. Pemberian } 1 / 3 \text { pupuk UREA } \\
\text { pada } 30-40 \mathrm{HST}\end{array}$ & $\begin{array}{l}\text { ANORGANIK, tanpa pupuk } \\
\text { kandang dan pupuk cair }\end{array}$ & \\
\hline & $\begin{array}{l}\text { d. Pemberian } 1 / 3 \text { pupuk UREA } \\
\text { pada } 50-60 \text { HST }\end{array}$ & d. Hanya pengaplikasian UREA & 2 \\
\hline & $\begin{array}{l}\text { e. Penambahan pupuk cair disetiap } \\
\text { penyemprotan }\end{array}$ & $\begin{array}{l}\text { e. Tidak ada pemupukan sama } \\
\text { sekali }\end{array}$ & 1 \\
\hline
\end{tabular}

Tabel 5. Pengukuran Variabel Pengairan

\begin{tabular}{lllr}
\hline \multicolumn{1}{c}{ Variabel } & \multicolumn{1}{c}{ Indikator } & \multicolumn{1}{c}{ Kriteria } & Skor \\
\hline \multirow{2}{*}{ Pengairan } & Pengontrolan ketinggian air di & a. $1-3$ hari sekali & 5 \\
& areal sawah, yaitu pada saat & b. $4-5$ hari sekali & 4 \\
& tabur / tanam, sawah tidak & c. 6 hari sekali & 3 \\
& digenangi, ketinggian debit air & d. 1 minggu sekali & 2 \\
& di areal persawahan sejalan & e. $>1$ minggu sekali & \\
& dengan pertumbuhan padi, dan & & \\
& mulai di keringkan 1 minggu & & \\
& sebelum panen, efisiennya & & \\
& dicek setiap 2-3 hari sekali & &
\end{tabular}


Tabel 6. Pengukuran Variabel Pengendalian hama dan Penyakit serta Gulma

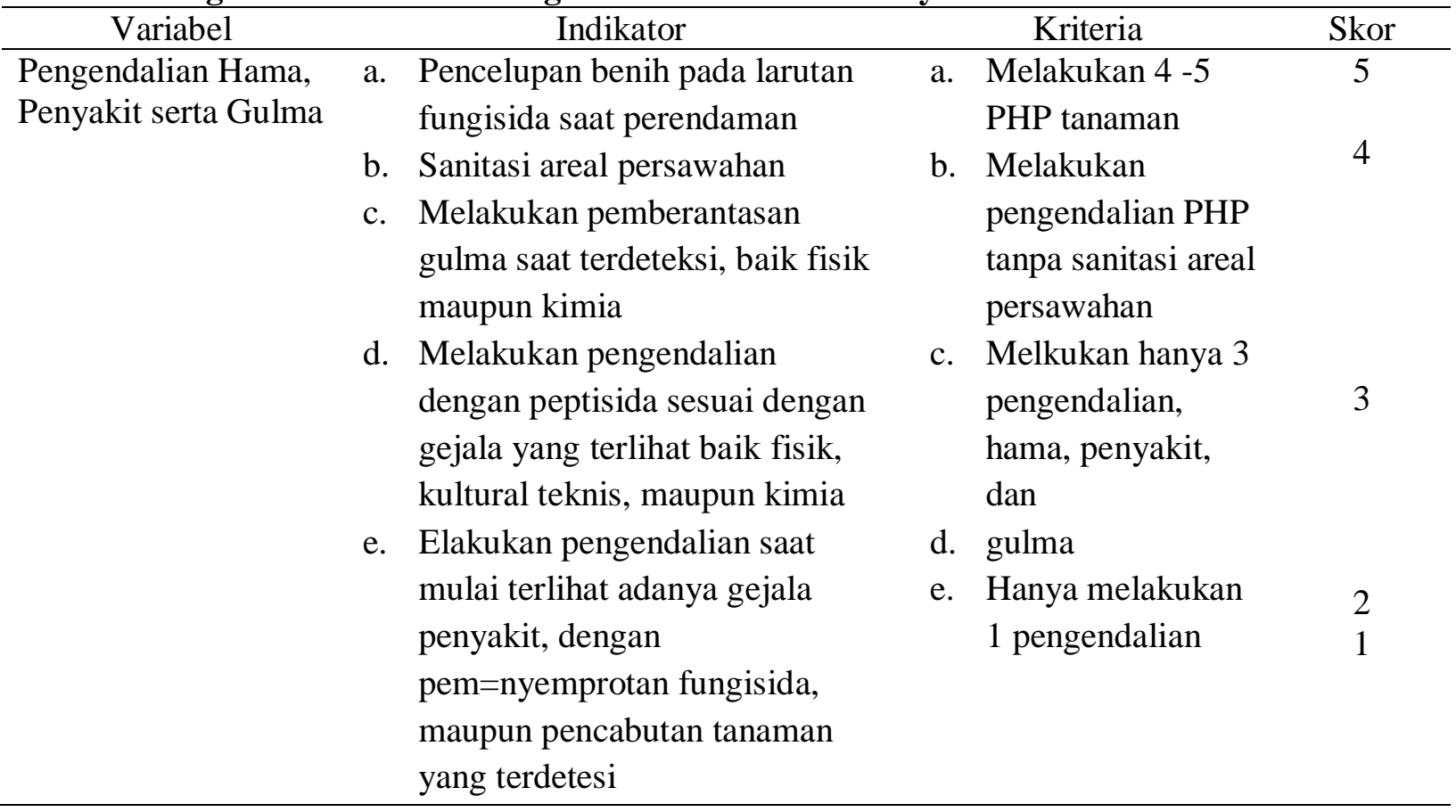

Tabel 7. Pengukuran Variabel Panen dan Pascapanen

\begin{tabular}{|c|c|c|c|}
\hline Variabel & Indikator & Kriteria & Skor \\
\hline \multirow[t]{5}{*}{$\begin{array}{l}\text { Panen dan pasca } \\
\text { panen }\end{array}$} & $\begin{array}{ll}\text { a. } & \text { Umur panen padi yang baik } \\
\text { adalah } 90-125 \mathrm{HST} \text {, atau } \\
\text { tergantung varietas }\end{array}$ & $\begin{array}{l}\text { a. melakukan semua kegiatan } \\
\text { panen dan pasca panen }\end{array}$ & 5 \\
\hline & $\begin{array}{l}\text { b. Pemanenan menggunakan } \\
\text { alat panen berupa sabit } \\
\text { (arit) bergerigi } \\
\text { c. Perontokan }\end{array}$ & $\begin{array}{l}\text { b. melakukan semua kegiatan } \\
\text { panen dan pasca panen, tanpa } \\
\text { melakukan penggilingan }\end{array}$ & 4 \\
\hline & $\begin{array}{l}\text { d. Pengangkutan ke tempat } \\
\text { penjemuran } \\
\text { e. Penjemuran hingga kadar } \\
\text { air mencapai } 14 \%\end{array}$ & $\begin{array}{l}\text { c. melakukan semua kegiatan } \\
\text { panen dan pasca panen, tanpa } \\
\text { melakukan penjemuran }\end{array}$ & 3 \\
\hline & f. penggilingan & $\begin{array}{l}\text { d. kegiatan hanya sampai pada } \\
\text { perontokan }\end{array}$ & 2 \\
\hline & & $\begin{array}{l}\text { e. tidak melakukan kegiatan } \\
\text { panen dan pascapanen }\end{array}$ & 1 \\
\hline
\end{tabular}

Panen padi dilakukan setelah berumur $90-125$ HST. Ciri - ciri fisik padi yang siap dipanen ialah bulir padi serta sebagian besar bagian tanaman telah telah berubah menjadi kuning secara keseluruhan. Proses penanganan Metode Analisis

Metode analisis menggunakan Analisis Statistik Deskriptif, dimana untuk mengkaji Karakteristik Sosial Ekonomi Petani dan Tingkat Adopsi Inovasi Teknologi Budidaya pascapanen yang baik maka kualitas gabah yang dihasilkan akan baik pula. Pengukuran variabel pada tahap panen dan pascapanen disajikan dalam bentuk Tabel 7 .

Padi ( Oryza sativa L.) menggunakan rumus Median. Sedangkan untuk mengetahui hubungan faktor-faktor sosial ekonomi petani dengan tingkat adopsi inovasi teknologi budidaya Padi (Oryza sativa L.) adalah dengan 
menggunakan uji korelasi Rank Spearman ( $\gamma$ s). Sedangkan untuk mengetahui nilai koefisien korelasi $(\gamma \mathrm{s})$ menggunakan Program SPSS 17.

Rumus :

\section{Keterangan}

$$
6 \sum_{i=1}^{N} d i^{2}
$$

$\gamma_{s}=$ Koefisien Korelasi Rank Spearman

$N=$ Jumlah Sampel

$d i=$ Selisih antara Ranking Variabel

Interpretasi hasil uji koefisien korelasi Rank Spearman ( $\gamma$ s) digunakan tabel sebagai berikut (Dahlan, 2011) :

Tabel 8. Panduan Interpretasi hasil uji koefisien korelasi Rank pearman

\begin{tabular}{ll}
\hline \multicolumn{1}{c}{ NILAI } & INTERPRETASI \\
\hline $0,00-0,199$ & Sangat Lemah \\
$0,20-0,399$ & Lemah \\
$0,40-0,599$ & Sedang \\
$0,60-0,799$ & Kuat \\
$0,80-1,000$ & Sangat Kuat
\end{tabular}

\section{HASIL DAN PEMBAHASAN}

\section{Gambaran Umum Lokasi Penelitian}

Penduduk Desa Kembang Mertha bukan merupakan penduduk asli Dataran Dumoga, melainkan penduduk transmigrasi asal pulau Bali pada tahun 1964, ketika meletusnya Gunung Agung. Adapun arti dan maksud dari pemberian nama desa ini adalah : Kembang artinya bertambah atau memperbanyak; sedangkan Mertha yang berasal dari kata Amertha yang berarti hidup atau menghidupkan, jadi mertha yang dimaksud adalah Rejeki (khususnya hasil pangan). Jadi Kembang Mertha artinya adalah memperbanyak rejeki (Maksum, 1990). Topografi Desa Kembang Mertha dengan ketinggian tempat 150 meter dpl ( diatas permukaan laut), dengan curah hujan setiap tahunnya rata-rata 180,79 $\mathrm{mm} /$ tahun, dan tekstur tanah lempung sehingga cocok untuk dijadikan sebagai areal persawahan.

Desa Kembang Mertha secara administrasi terletak di Kecamatan Dumoga Timur, Kabupaten Bolaang Mongondow dengan luas mencapai 30,82 $\mathrm{KM}^{2}$, berjarak 215 KM dari Kota Manado Ibukota Provinsi Sulawesi Utara atau dapat diakses dengan waktu tempuh kira kira 4 jam perjalanan, serta dapat diakses selama 50 Menit perjalanan dari Kota Kotamobagu yang berjarak kurang lebih 36 KM. Adapun batas- batas Desa Kembang Mertha adalah sebagai berikut :

- Sebelah utara berbatasan dengan Desa Pusian

- Sebelah selatan berbatasan dengan Desa Modomang

- Sebelah timur berbatasan dengan Areal Persawahan Pinonabuan dan desa Mokintop

- Sebelah barat berbatasan dengan Desa Dumoga.

Kearifan lokal masyarakat Desa Kembang Mertha masih sangat kental akan kebudayaan dan tradisi-tradisi masyarakat Bali pada umumnya dan pemeluk agama Hindu pada khususnya, masyarakat Kembang Mertha tidak hanya merayakan hari hari raya besar seperti Galungan dan Kuningan, Nyepi, Pagarwesi, Saraswatti dan sebagainya. Dalam budidaya padi, masyarakat Petani padi Bali pada umumnya dan masyarakat petani Padi di Desa Kembang Mertha pada khususnya mempunyai tradisi tersendiri.

Tradisi tersebut adalah sebagai berikut :

a. Ngaturang Pejati = dilaksanakan sebelum mengolah tanah. Merupakan permohonan berkat serta keselamatan kepada Tuhan Yang Maha Esa sebelum memulai semua kegiatan berusahatani padi.

b. Ngaturang Canang Sari $=$ dilaksanakan sesaat sebelum melakukan Penanaman. Bertujuan memohon dihindarkan dari segala halangan dan rintangan dalam penanaman.

c. Nulungin atau Tulung urip = dilaksanakan pada saat padi mulai tumbuh, Merupakan ucapan syukur kepada Tuhan Yang Maha Esa telah menolong (Tulung/diberkati) tanaman padi hingga dapat tumbuh.

d. Setiap purnama dan bulan mati (tilem) juga dihaturkan sesajen. Setiap purnama dan bulan mati (tilem) merupakan hari persembahyangan rutin umat Hindu atau 15 hari sekali. 
e. Biu kukung = dilaksanakan pada padi berumur 50 hari atau padi setelah bunting. Bertujuan memohon dihindarkan dari segala halangan, hama, dsb. Keunikan sesajen biu kukung ini adalah adanya tempat peletakan sesajen (sanggah) yang terbuat dari anyaman bambu dan tiang dari bambu, kayu atau sebagainya.

f. Nyangket $=$ dilaksanakan pada saat padi sudah kuning atau sebelum dilaksanakan proses pemanenan. Merupakan permohonan akan hasil yang melimpah, Nyangket dilakukan dengan cara mengikat segenggam batang padi dengan sesajen.

g. Ngerasakin = dilakukan setelah panen dan sebelum mengolah tanah. Merupakan ucapan syukur kepada Tuhan Yang Maha Esa atas hasil yang melimpah.

\section{Keadaan Penduduk}

Jumlah penduduk Desa Kembang Mertha pada tahun 2011 adalah 2.876 jiwa, yang terdiri dari 1.457 Laki-Laki atau 50,7\% dan perempuan 1.459 Perempuan atau 49,3 $\%$. Jumlah penduduk Desa Kembang Mertha tidak terdapat perbedaan yang signifikan antara jumlah penduduk laki-laki dan perempuan (Runtulalo, 2012). Mata pencaharian sebagian besar penduduk Desa Kembang Mertha ialah sektor pertanian, yaitu sebesar 64,33\%, Hal ini dikarenakan kondisi wilayah yang masih banyak terdapat lahan pertanian dan pekerjaan ini sudah dilakukan turun-temurun, banyak penduduk yang memiliki lebih dari satu pekerjaan atau pekerjaan sampingan. Jenis pekerjaan penduduk Desa Kembang Mertha secara rinci dilihat pada Tabel 9.

Pada tahun 2013, Desa Kembang Mertha dimekarkan menjadi 4 desa administratif, yaitu Desa Amertha Sari, Desa Amertha Buana, Desa Kembang Mertha (sebagai Desa Induk) dan Desa Kembang Sari. Namun, pada saat penelitian dilakukan, data desa-desa masih belum tersedia dikarenakan semua data administratif desa masih belum rampung.

\section{Karakteristik Responden}

Dalam penelitian ini terdapat 48 responden, yang secara keseluruhan berjenis
Tabel 9. Jenis Pekerjaan Penduduk Desa Kembang Mertha Tahun 2011

\begin{tabular}{cccc}
\hline No & Jenis Pekerjaan & $\begin{array}{c}\text { Jumlah } \\
\text { (orang) }\end{array}$ & \% \\
\hline 1 & Petani Padi Sawah & 1050 & 48,25 \\
2 & Petani Ladang & 47 & 2,16 \\
3 & Buruh Tani & 303 & 13,92 \\
4 & PNS & 274 & 12,59 \\
5 & TNI / POLRI & 153 & 7,03 \\
6 & Buruh Bangunan & 11 & 0,51 \\
7 & Pedagang & 254 & 11,67 \\
8 & Pengrajin & 26 & 1,19 \\
9 & Pensiunan & 58 & 2,67 \\
\hline & (PNS,TNI,POLRI) & & $\mathbf{1 0 0 , 0 0}$ \\
\hline
\end{tabular}

Sumber : BPS Kab, Bol-Mong

kelamin laki-laki, Responden merupakan petani padi yang ada di Desa Kembang Mertha.

Karakteristik yang digunakan dalam penelitian ini adalah Luas Lahan, Pendapatan, Pendidikan Formal, Pendidikan Non Formal, Umur, dan Tingkat Kekosmopolitan.

1. Luas Lahan

Luas lahan responden dihitung berdasarkan luas lahan usahatani yang dimiliki atau diusahakan oleh responden yang dinyatakan dalam hektar, disajikan dalam tabel : Dari Tabel 10 menunjukkan luas lahan yang diusahakan responden. Berdasarkan keterangan tersebut dapat disimpulkan bahwa luas lahan yang dimiliki oleh responden sebagian besar tergolong sedang dengan median 3. Meskipun sebagian besar lahan usahatani merupakan sawah tadah hujan dan seringkali tidak mendapat jatah pengairan irigasi, namun para petani tetap membudidayakan padi dengan mengeluarkan biaya ekstra yaitu memompa air sungai ataupun membuat sumur bor dengan harapan tetap menjaga produktifitas. 
2. Pendapatan

Pendapatan seseorang akan mempengaruhi tindaklanjut adopsi suatu inovasi, Petani dengan modal besar cenderung lebih berani dalam mencoba inovasi tersebut, Distribusi pendapatan responden disajikan dalam bentuk Tabel 11.

Dari Tabel 11 menunjukkan bahwa tingkat pendapatan petani tergolong tinggi dengan median 4. Hal ini mengisyaratkan dengan pendapatan responden yang lebih tinggi, responden lebih berani dalam mengambil keputusan untuk menerapkan inovasi baru, khususnya budidaya padi sawah, Pekerjaan responden selain sebagai petani padi juga berprofesi sebagai petani ladang, buruh tani, PNS, buruh bangunan, pedagang, pengerajin, dan pensiunan dan sebagainya.

\section{Pendidikan Formal}

Pendidikan formal yang ditempuh oleh responden dapat mempengaruhi pola pikir dalam menanggapi inovasi-inovasi baru yang diterimanya. Distribusi pendidikan formal responden disajikan dalam bentuk Tabel 12 . Berdasarkan Tabel 12 diuraikan tentang variabel tentang distribusi responden berdasarkan pendidikan formal, menunjukkan bahwa responden yang pendidikan formal dengan median 4, dapat disimpulkan tingkat kesadaran masyarakat akan pendidikan formal sudah tinggi.

\section{Pendidikan Non-Formal}

Pendidikan non formal dinyatakan dari berapa kali responden mengikuti kegiatan penyuluhan pertanian dalam 1 tahun terakhir, distribusi pendidikan non formal responden disajikan dalam bentuk Tabel 13.

Dari Tabel 13 menunjukkan pendidikan nonformal responden sebagian besar reponden termasuk dalam kategori rendah, yaitu dengan mengikuti kegiatan penyuluhan 1 sampai 4 kali dalam 1 tahun. Menurut keterangan petani, hal ini dikarenakan kurangnya kegiatan penyuluhan pertanian dari instansi-instansi terkait yang dilakukan di Desa Kembang Mertha. Kegiatan non-formal yang biasa diikuti petani itu merupakan kegiatan penyuluhan dan promosi produk dari perusahaan-perusahaan pestisida.

\section{Umur}

Umur petani akan mempengaruhi kemampuan fisik dan respon terhadap hal-hal baru dalam menjalankan usahataninya, , distribusi pendidikan non formal responden disajikan dalam bentuk Tabel 14 .

Umur akan berpengaruh terhadap pengambilan keputusan dan tindak-lanjut adopsi suatu inovasi seseorang. Dari Tabel 14 menunjukkan bahwa umur sebagian besar responden tergolong usia produktif, sehingga memungkinkan petani memilih untuk menerapkan suatu inovasi.

6. Tingkat Kekosmopolitan

Tingkat kekosmopolitan responden yang pergi keluar daerah untuk mencari informasi inovasi terbaru keluar kota dalam kurun waktu setahun, distribusi tingkat kosmopolitan responden disajikan dalam bentuk Tabel 15.

Tabel 10. Distribusi Responden Berdasarkan Luas Lahan

\begin{tabular}{llcccc}
\hline Variabel & Kriteria & skor & $\begin{array}{c}\text { Jumlah } \\
\text { responden }\end{array}$ & $\%$ & median \\
\hline \multirow{3}{*}{ Luas Lahan } & $>3 \mathrm{Ha}$ & & & & \\
& $2,1-3 \mathrm{Ha}$ & 4 & 4 & 17 & \\
& $1,1-2 \mathrm{Ha}$ & 3 & 19 & 40 & 3 \\
& $0,5-1 \mathrm{Ha}$ & 2 & 16 & 33 & \\
& $<0,5 \mathrm{Ha}$ & 1 & 1 & 2 &
\end{tabular}

Jumlah

48

100

Sumber : Analisis Data Primer 
Tabel 11. Distribusi Responden Berdasarkan Pendapatan per Musim Tanam

\begin{tabular}{|c|c|c|c|c|c|}
\hline Variabel & Kriteria & Skor & $\begin{array}{c}\text { Jumlah } \\
\text { responden }\end{array}$ & $\%$ & median \\
\hline \multirow{7}{*}{ Pendapatan } & $>\operatorname{Rp} 15,000,000$ & 5 & 15 & 31 & \multirow{7}{*}{4} \\
\hline & $\operatorname{Rp} 11,000,000-\operatorname{Rp} 15,000,000$ & 4 & 14 & 29 & \\
\hline & $\mathrm{Rp}, 7,500,000-\mathrm{Rp} 10,000,000$ & & & & \\
\hline & $\mathrm{Rp}, 5,000,000-\mathrm{Rp} \quad 7,000,000$ & 3 & 7 & 15 & \\
\hline & $<\mathrm{Rp}, 5,000,000$ & & & & \\
\hline & & 2 & 4 & 8 & \\
\hline & & 1 & 8 & 17 & \\
\hline Jumlah & & & 48 & 100 & \\
\hline
\end{tabular}

Sumber : Analisis Data Primer

Tabel 12. Distribusi Responden Berdasarkan Pendidikan Formal

\begin{tabular}{llcccc}
\hline \multicolumn{1}{c}{ Variabel } & Kriteria & Skor & $\begin{array}{c}\text { Jumlah } \\
\text { responden }\end{array}$ & \% & median \\
\hline & $>$ SMU/SMK & 5 & 11 & 23 & \\
Pendidikan & SMU/SMK & 4 & 14 & 29 & 4 \\
Formal & SMP & 3 & 11 & 23 & \\
& SD & 2 & 9 & 19 & \\
\hline \multicolumn{1}{c}{ Jumlah } & Tidak Tamat SD & 1 & 3 & 6 & \\
\hline
\end{tabular}

Sumber : Analisis Data Primer

Tabel 13. Distribusi Responden Berdasarkan Pendidikan non Formal

\begin{tabular}{llcccc}
\hline \multicolumn{1}{c}{ Variabel } & Kriteria & Skor & $\begin{array}{c}\text { Jumlah } \\
\text { responden }\end{array}$ & \% & median \\
\hline & $>12$ & 5 & 0 & 0 & \\
Pendidikan & $10-12 \mathrm{kali}$ & 4 & 0 & 0 & \\
nonformal & $5-9 \mathrm{kali}$ & 3 & 8 & 17 & \\
& $1-4 \mathrm{kali}$ & 2 & 27 & 56 & 2 \\
& Tidak Pernah & 1 & 13 & 27 & \\
\hline Jumlah & & & & & \\
\hline
\end{tabular}

Sumber : Analisis Data Primer

Tabel 14. Distribusi Responden Berdasarkan Umur

\begin{tabular}{llcccc}
\hline \multicolumn{1}{c}{ Variabel } & \multicolumn{1}{c}{ Kriteria } & skor & $\begin{array}{c}\text { Jumlah } \\
\text { responden }\end{array}$ & \% & median \\
& 25 - 39 Tahun & 5 & 17 & 35 & \\
\multirow{3}{*}{ Umur } & 40 - 50 Tahun & 4 & 13 & 27 & 4 \\
& 51 - 60 Tahun & 3 & 9 & 19 & \\
& 61 - 70 Tahun & 2 & 6 & 13 & \\
& >70Tahun & 1 & 3 & 6 & \\
\hline Jumlah & & & & 48 & 100 \\
\hline
\end{tabular}

Sumber : Analisis data primer 
Tabel 15. Distribusi Responden Berdasarkan Tingkat Kosmopolitan

\begin{tabular}{llcccc}
\hline \multicolumn{1}{c}{ Variabel } & Kriteria & skor & $\begin{array}{c}\text { Jumlah } \\
\text { responden }\end{array}$ & \% & median \\
\hline & $\geq 6$ kali & 5 & 9 & 19 & \\
Tingkat & 5 kali & 4 & 5 & 10 & \\
Kekosmopolitan & 4 kali & 3 & 3 & 6 & 2 \\
& 3 kali & 2 & 7 & 15 & 2 \\
& $1-2$ kali & 1 & 24 & 50 & \\
\hline \multicolumn{1}{c}{ Jumlah } & & & & & \\
\hline
\end{tabular}

Sumber : Analisis Data Primer

Tingkat kekosmopolitan dapat dilihat dari frekuensi dan jarak kegiatan bepergian maupun pemanfaatan media massa. Dari Tabel 15 menunjukkan tingkat kekosmopolitan sebagian besar responden tergolong rendah dengan median 2.

a. Adopsi Responden Terhadap Budidaya Padi (Oryza sativa L,)

Tingkat adopsi responden terhadap budidaya padi meliputi pengolahan tanah, penanaman, pemupukan, pengairan, pengendalian hama, penyakit dan gulma, dan panen dan pasca panen.

1. Pengolahan Tanah

Pengolahan Tanah bertujuan untuk mempersiapkan media tanam untuk pertanaman padi meliputi pembersihan lahan, pembongkaran lapisan tanah, pelumpuran, dan pembuatan pematang sawah dengan bantuan cangkul. Distribusi tahap pengolahan tanah disajikan dalam bentuk Tabel 16.

Pengolahan Tanah, yaitu persiapan lahan yang akan ditanami, Pengolahan dilakukan dengan bajak ataupun traktor, dari Tabel 16 menunjukkan keseluruhan responden melakukan pengolahan tanah dengan sangat baik, yaitu dengan median 5 . Menurut keterangan, hal ini karena para responden telah mengenal teknik pengolahan lahan secara turun temurun dari orang tua mereka, hanya saja terdapat perbedaan pada peralatan yang mereka gunakan, Oleh karena itu, dengan penggunaan traktor yang mempersingkat waktu pengolahan tanah dan menghemat tenaga kerja berdampak pada pertanian di Desa Kembang Mertha cenderung berkembang.

\section{Penanaman}

Penanaman dimulai dari Penjemuran benih selama 1-2 jam kemudian melakukan seleksi benih dengan merendam, benih yang baik adalah yang tenggelam. Selanjutnya pengaplikasian fungisida, dicampur bersama air rendaman benih terpilih kemudian ditiriskan. Pemeraman selama \pm 48 jam dan benih ditabur pada areal penanaman dengan kerapatan $\pm 50 \mathrm{gr} / 1 \mathrm{~m}^{2}$. Distribusi tahap Penanaman disajikan dalam bentuk Tabel 17.

\section{Dari Tabel 17 menunjukkan} keseluruhan responden $(100 \%)$ melakukan 5 tahapan penanaman dengan sangat baik dengan median 5. Hal ini disebabkan oleh teknik penanaman TABELA yang sangat menghemat waktu dan tenaga kerja.

1. Pemupukan

Pemupukan dimaksudkan untuk mempertahankan unsur-unsur hara yang ada dalam tanah. Pada dasarnya, unsur - unsur hara makro yang dibutuhkan tanaman ialah unsur N (Nitrogen), unsur P (Phospor), dan unsur K (Kalium), terdapat pada pupukpupuk organik maupun anorganik. Pemberian pupuk ini juga perlu memperhatikan kebutuhan tanaman, baik dosis maupun waktu pengaplikasian. Distribusi tahap pemupukan disajikan dalam bentuk Tabel 18 .

Dari Tabel 18 menunjukkan bahwa pengetahuan tentang pupuk dan pemupukan sudah sangat tinggi yaitu dengan median 4, dapat dilihat dari pengaplikasian jenis-jenis pupuk pada lahan usahatani. Menurut keterangan responden alasan tidak digunakannya pupuk kandang karena alasan efisiensi waktu, tenaga dan modal. 
Tabel 16. Distribusi Responden Berdasarkan Pengolahan Tanah

\begin{tabular}{|c|c|c|c|c|c|}
\hline Variabel & Kriteria & skor & $\begin{array}{c}\text { Jumlah } \\
\text { responden }\end{array}$ & $\%$ & median \\
\hline \multirow{5}{*}{$\begin{array}{l}\text { Pengolahan } \\
\text { tanah }\end{array}$} & $\begin{array}{l}\text { a. Melakukan 5-6 tahapan } \\
\text { pengolahan tanah }\end{array}$ & 5 & 48 & 100 & 5 \\
\hline & $\begin{array}{l}\text { b. Melakukan } 3 \text { - } 4 \text { tahapan } \\
\text { pengolahan tanah }\end{array}$ & 4 & 0 & 0 & \\
\hline & $\begin{array}{l}\text { c. Melakukan } 2 \text { tahapan pengolahan } \\
\text { tanah }\end{array}$ & 3 & 0 & 0 & \\
\hline & $\begin{array}{l}\text { d. Melakukan } 1 \text { tahapan pengolahan } \\
\text { tanah }\end{array}$ & 2 & 0 & 0 & \\
\hline & $\begin{array}{l}\text { e. Tidak melakukan tahapan } \\
\text { pengolahan tanah }\end{array}$ & 1 & 0 & 0 & \\
\hline
\end{tabular}

Sumber : Analisis Data Primer

Tabel 17. Distribusi Responden Berdasarkan Penanaman

\begin{tabular}{|c|c|c|c|c|c|}
\hline Variabel & Kriteria & skor & Jumlah & $\%$ & median \\
\hline \multirow{5}{*}{ Penanaman } & a. Melakukan 5 tahapan penanaman & 5 & 48 & 100 & \multirow[t]{6}{*}{5} \\
\hline & b. Melakukan 4 tahapan penanaman & 4 & 0 & 0 & \\
\hline & c. Melakukan 3 tahapan penanaman & 3 & 0 & 0 & \\
\hline & d. Melakukan 2 tahapan penanaman & 2 & 0 & 0 & \\
\hline & $\begin{array}{l}\text { e. Melakukan hanya } 1 \text { tahapan } \\
\text { penanaman }\end{array}$ & 1 & 0 & 0 & \\
\hline Jumlah & & & 48 & 100 & \\
\hline
\end{tabular}

Sumber : Analisis Data Primer

Tabel 18. Distribusi Responden Berdasarkan Pemupukan

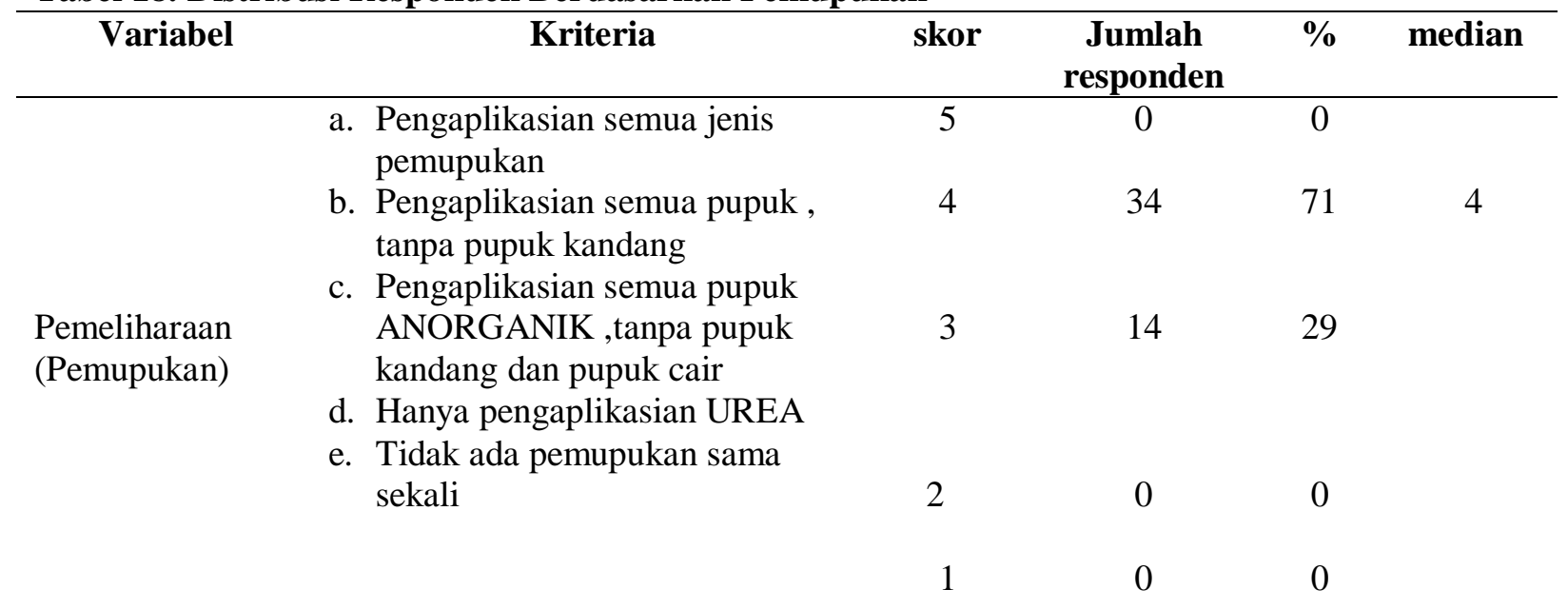

Jumlah

48

100

Sumber : Analisis Data Primer 


\section{Pengairan}

Salah satu kunci keberhasilan budidaya padi ialah metode pengairan yang teratur. Tidak hanya untuk kebutuhan tanaman padi, namun juga berpengaruh pada pengendalian hama, penyakit dan gulma. Oleh karena itu, pengontrolan ketinggian genangan air pada lahan sawah menjadi sangat penting dalam budidaya padi sawah. Distribusi tahap pengairan disajikan dalam bentuk Tabel 19 .

Dari Tabel 19 dapat dilihat bahwa para responden sangat memperhatikan genangan air pada lahan usahatani, adalah sangat tinggi yaitu dengan median 5. Menurut keterangan responden pengontrolan air dipengaruhi oleh letak areal pertanaman padi itu sendiri, jika dekat dengan jalur irigasi maka pengontrolan sedikit dilonggarkan, dan sebaliknya. Seperti yang diketahui areal sawah yang ada di Desa Kembang Mertha seringkali tidak mendapat jatah pengairan yang tepat waktu, upaya para petani ialah membuat sumur bor ataupun membendung aliran air sungai.

3. Pengendalian Hama Penyakit dan Gulma

Pengontrolan rutin terhadap gejala serangan hama dan penyakit, serta gulma yang muncul pada areal pertanaman padi sawah menjadi kunci keberhasilan mempertahankan produksi, disamping itu juga mengurangi resiko gagal panen. Pengendalian dilakukan apabila terdapat gejala serangan, dapat dilakukan secara fisik, biologis, kimia, maupun kultur tenis. Distribusi tahap pengendalian hama, penyakit dan gulma disajikan dalam bentuk Tabel 20 . Dari Tabel 20 dapat dilihat bahwa tindakan responden terhadap pengendalian hama, penyakit serta gulma sangat tinggi, yaitu dengan median 5. Sejak metode penanaman Tabela mulai diaplikasikan di Desa Kembang Mertha, pengendalian hama, penyakit serta gulma lebih mengarah kepada pengendalian secara kimia, yaitu dengan penggunaan berbagai jenis pestisida, namun dari keterangan beberapa responden masih ada beberapa yang dilakukan secara teknis.

\section{Panen dan Pascapanen}

Panen padi dilakukan setelah berumur $90-125$ HST, Ciri - ciri fisik padi yang siap dipanen ialah bulir padi serta sebagian besar bagian tanaman telah telah berubah menjadi kuning secara keseluruhan. Proses penanganan pascapanen yang baik maka kualitas gabah yang dihasilkan akan baik pula. Distribusi tahap pengendalian hama, penyakit dan gulma disajikan dalam bentuk Tabel 21 .

Dari Tabel 21 dapat dilihat bahwa kegiatan panen dan pascapanen padi yang dilakukan petani di Desa Kembang Mertha sudah sangat baik, yaitu dengan median 5 . Menurut keterangan responden, dengan adanya kerjasama yang terjalin antara petani dan pemilik gilingan padi, hasil panen yang dapat langsung dilakukan penjemuran di tempat yang sudah disediakan pemilik gilingan.

\section{Tabel 19. Distribusi Responden Berdasarkan Pengairan}

\begin{tabular}{llcccc}
\hline \multicolumn{1}{c}{ Variabel } & \multicolumn{1}{c}{ Kriteria } & skor & $\begin{array}{c}\text { Jumlah } \\
\text { responden }\end{array}$ & \% & median \\
& 2-3 hari sekali & 5 & 36 & 75 & 5 \\
& 4-5 hari sekali & 4 & 9 & 19 & \\
Pemeliharaan & 6 hari sekali & 3 & 2 & 4 & \\
(Pengairan) & 1 minggu sekali & 2 & 1 & 2 & \\
& $>$ 1 minggu sekali & 1 & 0 & 0 &
\end{tabular}

Jumlah

48

100

Sumber : Analisis Data Primer 
Tabel 20. Distribusi Responden Berdasarkan Pengendalian Hama Penyakit dan Gulma

\begin{tabular}{|c|c|c|c|c|c|}
\hline Variabel & Kriteria & skor & $\begin{array}{l}\text { Jumlah } \\
\text { responden }\end{array}$ & $\%$ & median \\
\hline \multirow{5}{*}{$\begin{array}{l}\text { Pengendalian } \\
\text { Hama, Penyakit } \\
\text { dan Gulma }\end{array}$} & $\begin{array}{l}\text { a. Melakukan } 4 \text { - } 5 \text { kegiatan PHP } \\
\text { tanaman }\end{array}$ & 5 & 37 & 77 & 5 \\
\hline & $\begin{array}{l}\text { b. Melakukan pengendalian PHP } \\
\text { tanpa sanitasi areal } \\
\text { persawahan }\end{array}$ & 4 & 11 & 23 & \\
\hline & $\begin{array}{l}\text { c. Melakukan hanya } 3 \\
\text { pengendalian, hama, penyakit, } \\
\text { dan gulma }\end{array}$ & 3 & 0 & 0 & \\
\hline & $\begin{array}{l}\text { d. Hanya melakukan } 2 \\
\text { pengendalian, hama dan } \\
\text { penyakit }\end{array}$ & 2 & 0 & 0 & \\
\hline & $\begin{array}{l}\text { e. Hanya melakukan } 1 \\
\text { pengendalian }\end{array}$ & 1 & 0 & 0 & \\
\hline
\end{tabular}

Jumlah

$48 \quad 100$

Sumber : Analisis Data Primer

Tabel 21. Distribusi Responden Berdasarkan Panen dan Pascapanen

\begin{tabular}{|c|c|c|c|c|c|}
\hline Variabel & Kriteria & skor & $\begin{array}{c}\text { Jumlah } \\
\text { responden }\end{array}$ & $\%$ & median \\
\hline $\begin{array}{l}\text { Panen dan } \\
\text { Pascapanen }\end{array}$ & $\begin{array}{l}\text { a. melakukan semua kegiatan } \\
\text { panen dan pasca panen } \\
\text { b. melakukan semua kegiatan } \\
\text { panen dan pasca panen, tanpa } \\
\text { melakukan penggilingan } \\
\text { c. melakukan semua kegiatan } \\
\text { panen dan pasca panen, tanpa } \\
\text { melakukan penjemuran } \\
\text { d. kegiatan hanya sampai pada } \\
\text { perontokan } \\
\text { e. tidak melakukan kegiatan } \\
\text { panen dan pascapanen }\end{array}$ & $\begin{array}{l}2 \\
1\end{array}$ & $\begin{array}{l}0 \\
0\end{array}$ & $\begin{array}{l}0 \\
0\end{array}$ & 5 \\
\hline
\end{tabular}

\begin{tabular}{|c|c|}
\hline Jumlah & 100 \\
\hline Sumber : Analisis Data Primer & \\
\hline $\begin{array}{l}\text { Hubungan Faktor-Faktor } \begin{array}{c}\text { Sosial Ekonomi } \\
\text { Petani Dengan Tingkat } \\
\text { Budidaya Padi }\end{array} \\
\text { Adopsi Inovasi }\end{array}$ & $\begin{array}{l}\text { umur, dan tingkat kekosmopolitan. Sedangkan } \\
\text { tingkat adopsi inovasi budidaya padi diperoleh } \\
\text { dari penjumlahan skor dari pengolahan tanah, }\end{array}$ \\
\hline $\begin{array}{l}\text { Faktor-Faktor Sosial ekonomi yang } \\
\text { diteliti meliputi luas lahan, pendapatan, } \\
\text { pendidikan formal, pendidikan non formal, }\end{array}$ & $\begin{array}{l}\text { penanaman, pemupukan, pengairan, } \\
\text { pengendalian hama, penyakit dan gulma, dan } \\
\text { panen dan pasca panen. }\end{array}$ \\
\hline
\end{tabular}


Tabel 22. Hubungan Faktor-Faktor Sosial Ekonomi terhadap Tingkat Adopsi Inovasi Budidaya Tanaman Padi.

\begin{tabular}{ccc}
\hline $\begin{array}{c}\text { Faktor Sosial } \\
\text { Ekonomi }\end{array}$ & $\begin{array}{c}\text { Adopsi Inovasi Budidaya } \\
\text { Padi }\end{array}$ & $\begin{array}{c}\text { Sig. (2- } \\
\text { Tailed) }\end{array}$ \\
\hline Luas Lahan & 0,468 & 0,001 \\
Pendapatan & 0,419 & 0,003 \\
Pendidikan & 0,322 & 0,026 \\
$\quad$ Formal & & \\
Pendidikan Non & 0,019 & 0,896 \\
$\quad$ Formal & & \\
$\quad$ Umur & $-0,048$ & 0,746 \\
Kosmopolitan & 0,401 & 0,005 \\
\hline Sum
\end{tabular}

Sumber : Analisis Data Primer

Tabel 22 menunjukkan korelasi luas lahan, pendapatan, pendidikan formal, pendidikan non formal, umur responden, serta tingkat kekosmopolitan responden. Nilai significancy menunjukkan hubungan 2 arah, sedangkan kekuatan hubungan dapat dilihat dari nilai korelasi Rank Spearman.

a. Korelasi luas lahan terhadap adopsi inovasi padi

Tabel 22 menunjukkan nilai significancy sebesar 0,01 menyatakan hubungan sangat nyata antara keduanya. Artinya, luas lahan berpengaruh sangat nyata terhadap tingkat adopsi inovasi budidaya padi, semakin luas lahan usahatani seseorang, maka semakin tinggi pula tingkat adopsinya terhadap inovasi-inovasi budidaya padi yang ditawarkan. Nilai korelasi Spearman sebesar 0,468 menunjukkan bahwa arah korelasi positif dengan kekuatan korelasi sedang, petani dengan lahan yang lebih luas cenderung mencoba inovasi untuk hasil yang lebih maksimal.

b. Korelasi pendapatan terhadap adopsi inovasi tanaman padi

Dari tabel 20 diperoleh nilai significancy sebesar 0,03 yang menunjukkan hubungan sangat nyata antara keduanya. Artinya, pendapatan berpengaruh nyata terhadap tingkat adopsi inovasi budidaya padi. Nilai korelasi Spearman sebesar 0,491 menunjukkan bahwa arah korelasi positif dengan kekuatan korelasi sedang, Semakin tinggi pendapatan seseorang, maka semakin tinggi pula tingkat adopsinya terhadap inovasiinovasi budidaya padi yang ditawarkan, alasan ketersediaan modal merupakan faktor pendukung untuk mengadopsi inovasi yang ditawarkan.

c. Korelasi luas pendidikan formal adopsi inovasi tanaman padi

Dari tabel 20 diperoleh nilai significancy sebesar 0,26 yang menunjukkan hubungan nyata antara keduanya. Artinya, Pendidikan formal berpengaruh nyata terhadap tingkat adopsi inovasi budidaya padi. Nilai korelasi Spearman sebesar 0,322 menunjukkan bahwa arah korelasi positif dengan kekuatan korelasi lemah, Jenjang pendidikan mempengaruhi pada pola pikir, komunikasi, serta wawasan seseorang. Dalam hal ini akan lebih mudah seseorang dalam memahami maksud dan tujuan serta informasi suatu inovasi, petunjuk penggunaan, buku panduan, dsb.

d. Korelasi pendidikan non formal terhadap adopsi inovasi tanaman padi

Dari tabel 20 diperoleh nilai significancy sebesar 8,96 yang menunjukkan hubungan tidak nyata antara keduanya. Tidak ada hubungan antara pendidikan non formal dan adopsi inovasi budidaya padi diakibatkan oleh kurangnya penyuluhan-penyuluhan yang dilakukan di Desa Kembang Mertha Bersatu. Nilai korelasi Spearman sebesar 0,019 menunjukkan bahwa arah korelasi positif dengan kekuatan korelasi sangat lemah, jadi pendidikan non formal walau hampir tidak berarti tetap mempengaruhi keputusan seseorang untuk mengadopsi inovasi yang ditawarkan. Hal ini menunjukkan walaupun seseorang yang jarang bahkan tidak pernah mengikuti kegiatan penyuluhan sekalipun dapat menerapkan suatu inovasi, meski informasi yang didapat bukan berasal penyuluh secara langsung, melainkan dari sesama petani yang telah menerapkan terlebih dahulu menerapkan, Dalam hal ini hanya berperan sebagai pengikut akhir (skeptist).

e. Korelasi umur terhadap adopsi inovasi tanaman padi

Dari tabel 20 diperoleh nilai significancy sebesar 7,46 yang menunjukkan hubungan tidak nyata antara keduanya. Artinya, 
juga tidak ada hubungan antara umur dan adopsi inovasi budidaya padi dikarenakan responden masih merupakan petani dengan golongan umur produktif. Nilai korelasi Spearman sebesar -0,048 menunjukkan bahwa arah korelasi negatif (berlawanan arah) dengan kekuatan korelasi sangat lemah, Hal ini menunjukkan bahwa umur responden tidak diikuti oleh tingginya tingkat adopsi inovasi budidaya padi, hal ini dikarenakan petani pada kelompok umur tua pasif dalam mencari dan masih sangat ragu-ragu untuk mencoba inovasi-inovasi baru sebab semua tindakan berorientasi pada pengalaman mereka selama ini.

f. Korelasi tingkat kosmopolitan terhadap adopsi inovasi tanaman padi

Tabel 20 diperoleh nilai significancy sebesar 0,05 yang menunjukkan hubungan sangat nyata antara keduanya, jadi tingkat kosmopolitan berpengaruh sangat nyata terhadap tingkat adopsi inovasi budidaya padi. Nilai korelasi Spearman sebesar 0,401 menunjukkan bahwa arah korelasi positif dengan kekuatan korelasi sedang. Hal ini menunjukkan bahwa kekosmopolitan seseorang memungkinkan seseorang ingin menambah wawasan tentang budidaya padi serta pembaruan inovasi-inovasi terbaru yang ingin dicoba.

\section{KESIMPULAN DAN SARAN}

\section{Kesimpulan}

Dari hasil penelitian yang dilakukan di Desa Kembang Mertha Bersatu, disimpulkan bahwa responden sudah pada tahap mengadopsi inovasi. Nilai Significancy menunjukkan luas lahan, pendapatan, dan tingkat kosmopolitan memiliki hubungan sangat nyata terhadap tingkat adopsi inovasi budidaya padi (Oryza sativa L.), pendidikan formal menunjukkan hubungan nyata terhadap tingkat adopsi inovasi budidaya padi (Oryza sativa L.), sedangkan pendidikan non formal dan umur menunjukkan hubungan yang tidak nyata terhadap tingkat adopsi inovasi budidaya padi (Oryza sativa L.)

Nilai korelasi Spearman luas lahan, pendapatan, pendidikan formal, pendidikan non formal dan tingkat kosmopolitan menunjukkan arah korelasi positif, sedangkan umur menunjukkan arah korelasi negatif terhadap tingkat adopsi inovasi budidaya padi (Oryza sativa $L$.)

\section{Saran}

1. Hendaknya instansi pemerintah terkait, dalam hal ini Dinas Pertanian lebih meningkatkan intensitas penyuluhan, misalnya dengan melakukan penyuluhan secara rutin atau dengan menambah jumlah penyuluh di tiap-tiap desa maupun kecamatan, hal ini dimaksudkan agar kegiatan penyuluhan bisa dilakukan secara rutin dan berkelanjutan, dengan begitu para petani padi di Desa Kembang Mertha (Bersatu) maupun petani di Kecamatan Dumoga pada khususnya mendapat pelatihan budidaya yang baik dan benar sesuai anjuran, guna tercapainya tujuan better farming, better business dan better living.

2. Hendaknya pemerintah memberlakukan sistem yang lebih baik lagi dalam penyaluran air irigasi yang ada, dikarenakan petani padi di Desa Kembang Mertha dan Sekitarnya masih sering terlambat mendapat jatah pengairan, sehingga menggangu kegiatan budidaya tanaman padi.

\section{DAFTAR PUSTAKA}

Anonim, 2000. Budidaya pertanian " Padi (Oryza sativa)"

http://syekhfanismd.lecture.ub.ac.id/file s/2013/03/PADI-PUSRI.pdf. Diakses pada 30 Oktober 2014

Dahlan M,S. 2010. Statistik Untuk Kedokteran dan Kesehatan (Deskriptif, Bivariat, dan Multivariat Dilengkapi Aplikasi Dengan SPSS). Salemba Medika. Jakarta.

Ibrahim J,T , Sudiyono A, Harpowo, 2003. Komunikasi dan Penyuluhan Pertanian, Bayumedia Publishing. Malang.

Levis, L,R, 1996. Komunikasi Penyuluhan Pedesaan. Citra Aditya Bakti. Bandung. 
Maksum M, 1990. Sejarah Desa Kembang Mertha Kecamatan Dumoga. Kembang Mertha.

Mardikanto T, 1993. Penyuluhan Pembangunan Pertanian. UNS Press. Surakarta.

$$
\text { 2010. Konsep-Konsep }
$$

Pemberdayaan Masyarakat. UNS Press. Surakarta.

$$
\text { 2010. Model-Model }
$$

Pemberdayaan Masyarakat. UNS Press. Surakarta.

Panelewen J,H, 2010. Kebijakan dan program Peningkatan Produktivitas Padi Untuk Mewujudkan Swasembada Beras dan Swasembada Pangan Berkelanjutan di Provinsi Sulawesi Utara. Jurnal Pertanian. Manado. Dinas Pertanian dan Peternakan Sulawesi Utara.

(http://sulut.litbang.pertanian.go.id/ind/i ndex.php?option=com_phocadownload $\&$ view $=$ category $\& \mathrm{id}=7$ :prosidingtahun-2011\&download=72:kebijakandan-program-peningkatanproduktivitas-padi-untuk-mewujudkanswasembada-beras-dan-swasembadapangan-berkelanjutan-di-provinsisulawesi-utara-j.-h.-

panelewen\&Itemid=1). Di akses pada tanggal 30 Oktober 2014.

Prasetyo Y.T. 2002. Budidaya Padi Sawah TOT (Tanpa Olah Tanah). Kanisus, Yogyakarta.
Runtulalo, J, 2011. Profil Kecamatan seKabupaten Bolaang Mongondow, Kotamobagu. Badan Pusat Statistik Kabupaten Bolaang Mongondow. (https://humasbolmong.files.wordpress.co $\mathrm{m} / 2011 / 11$ /profil-kecamatan-se-kabbolmong-2011.pdf). Di unduh pada tanggal 10 November 2014.

Setiana, L. 2005. Teknik Penyuluhan dan Pemberdayaan Masyarakat. Ghalia Indonesia. Bogor.

Soehartono, I, 2004. Metode Penelitian Sosial. PT. Remaja Rosdakarya, Bandung.

Slamet, M. 2000. Dasar - dasar Penyuluhan dan Modernisasi Pertanian. Penerbit Bina Cipta. Bandung.

Slamet, M. 2000. Dasar - dasar Penyuluhan dan Modernisasi Pertanian. Penerbit Bina Cipta. Bandung.

Sukino, 2013. Membangun Pertanian Dengan Pemberdayaan Masyarakat Tani (Terobosan Menanggulangi Kemiskinan). Pustaka Baru Press. Yogyakarta.

Syahyuti, 2006. 30 Konsep Penting Dalam Pembangunan Pedesaan dan pertanian. Penjelasan tentang konsep, istilah, teori dan indikator serta variabel. Bina Rena Pariwara, Jakarta.

Syamsudin S, 2000.Dasar - dasar Penyuluhan dan Modernisasi Pertanian. Penerbit Bumi Aksara. Jakarta.

Van den Ban, A.W. dan H.S. Hawkins. 1999. Penyuluhan Pertanian. Penerbit Kanisius. Yogyakarta. 